\title{
The Effect of Inoculum Type and Mycorrhiza Dosage on Growth and Production of Mung Bean Vigna Radiata L.
}

\section{Syamsuddin Djauhari ${ }^{*}$, Jami'at Dwi Elriyono, Bambang Tri Rahardjo}

Department of Plant Pest and Diseases, Faculty of Agriculture, University of Brawijaya Jl. Veteran, Malang 65145, East Java, Indonesiaa

Submitted 25August 2020 Accepted 29 October 2020

Corresponding author Syamsuddin Djauhari; dsyamsuddin@gmail.com

\section{ABSTRACT}

Mung bean (Vigna radiata L.) is the third most essential legume crop commodity after soybeans and peanuts. Mung bean production faced problems of nutrientpoor land and soil texture that does not support soybean growth. The solution to overcome these obstacles is the application of mycorrhizae in nutrient-poor soils. This study aimed to determine the effect of various inoculums and mycorrhizal doses on growth and production in mung beans. This study used a Completely Randomized Design with nine treatments and three replications. The research included mycorrhizal inoculation with various treatments, as well as observations with variable plant height, plant biomass, number of pods, wet weight and dry weight of pods, the weight of 50 wet and dry seeds, mycorrhizal infection in roots, and number of spores in $100 \mathrm{gr}$ of soil. The data were analyzed by SPSS 15.0 program for ANOVA. The results indicated that granular $(30 \mathrm{gr})$ had the highest plant height of $(41.33 \mathrm{~cm})$, crown weight $(30.69 \mathrm{gr})$, number of pods, wet and dry pod weight is $13.66,9.84 \mathrm{gr}$, and $8.86 \mathrm{gr}$, respectively, $50 \mathrm{~kg}$ of wet and dry weight (3.82 and 3.20) and the highest effect on the number of spores at 29.33. The $30 \mathrm{gr}$ tablets treatment showed the highest results on root weight $(22.98 \mathrm{gr})$, while the $30 \mathrm{gr}$ mixture showed the highest results on the percentage of infection $(73.33 \%)$.

Keywords: Mung been; Glomus sp.; Acaulospora sp.; Mycorrhiza spore

\section{INTRODUCTION}

The third most valuable commodity of legumes after soybeans and peanuts is mung-beans (Vigna radiata L.) (Ramadhani et al., 2020). Mung beans are agricultural commodities with valuable prospects for Indonesia because of the increasing demand for consumption and industry (Widiyawati et al., 2016). Mung bean production in Indonesia decreased from 341,342 tons per year in 2011 to 271,463 tons per year in 2015 (Hastuti et al., 2018). Various factors decrease the production of Mung beans, including low soil fertility and soil texture that does not support the growth of Mung beans Efforts to increase the productivity of Mung beans can be done by using mycorrhizae.

Mycorrhiza is a fungus that can affect symbiosis with most (97\%) plant families such as food, horticulture, forestry, and plantations (Chen et al., 2018). Mycorrhizae help increase plant growth on marginal lands (Samanhudi et al., 2017). Mycorrhiza can increase nutrient uptake for plants, especially phosphate nutrients $(P)$ (Campos et al., 2018). Mycorrhizae produce phosphatase enzymes that can release $\mathrm{P}$ and $\mathrm{Al}$ elements bound in acidic soil and $\mathrm{Ca}$ in calcareous so that $\mathrm{P}$ 


\section{MATERIALS AND METHODS}

This research was conducted in the STTP 2 Tanjung Malang and the Plant diseases laboratory of Plant Pest and Diseases, Faculty of Agriculture, Brawijaya University, from March 2014 to February 2015. This study employed a completely randomized design. This study was used nine treatments, namely mixture $(10,20$, and $30 \mathrm{gr})$, tablets $(10,20$, and $30 \mathrm{gr})$, and granular $(10,20$, and $30 \mathrm{gr}$ ), and each treatment was repeated three times.

\section{Exploration of mycorrhizal inoculum}

Mycorrhizal exploration was carried out on six corn planting areas, i.e., Tumpang, Ngijo, Dau, Jatikerto, Joyogrand, and Karangploso Sub-District, Malang District. Sampling was carried out around corn roots by cleaning the corn roots area with a distance of $0.5 \mathrm{~cm}^{2}$ from other plants. Then the soil and roots were taken (25-30 cm deep). The soil was put into a plastic clip and stored at room temperature.

\section{Mycorrhizal extraction and identification}

The soil from plant roots was filtered by the procedure of (Tommerup, 1992). The soil was put into a measuring cup filled with water, stirred until it was homogenous. Then allowed to stand for 15 seconds, the suspension was poured into a level four filter with successive hole diameters from top to bottom was $0.300,0.180,0.063$, and $0.038 \mathrm{~mm}$. The material remaining from the $0.063 \mathrm{~mm}$ and $0.038 \mathrm{~mm}$ sieve were washed with tap water and aged in centrifuge tubes as a suspension until a volume of $20 \mathrm{ml}$ was added to $60 \%$ sugar solution. Then in the centrifuge for 7 minutes at $2000 \mathrm{rpm}$. Then the centrifuge suspension was filtered again with a $0.038 \mathrm{~mm}$ filter. The results on the $0.038 \mathrm{~mm}$ sieve were cleaned with distilled water and poured into a petri dish, and then observation was carried out under a microscope to identify spores. The identify spores of mycorrhizal was used Melzer's Reagent. Melzer's Reagent was made from 1.5 gram KI, 0.5-gram lodine, 20-gram Chloral Hydrate, and $20 \mathrm{ml}$ aqua dest. The characteristics of mycorrhizal spores could be compared in mycorrhizal spore collections on the website http:// invam.wvu.edu. The spores were obtained from wet sifting were collected in a certain amount and then sterilized the surface of the spores repeatedly until clean. The material used to sterilize spores was $2 \%$ chlorox. The sterile spores were placed in sterile distilled water. Every $20 \mathrm{ml}$ of water was put into 20 spores of each genus.

\section{Propagation of mycorrhizae}

Mycorrhizal propagation was done using corn plants. Propagation was intended to obtain enough mycorrhiza for inoculation. For propagation, sterile soil and sand (ratio of 1:1) was used and put into a heat-resistant plastic bag. Then put the spore solution in the hole that had been given a filter paper container. In the right above the hole, prepared corn seeds and kept the plants for 60 days. Harvesting was done by dismantling the host plant, cutting into small pieces of plant roots using scissors, mixing the root pieces with soil from the plant, and then packing in a plastic bag.

\section{Research implementation}

Three types of mycorrhizal inoculation were used, i.e., granular, mixed, and tablet. Inoculation was repeated with $3 \mathrm{~cm}$ depth. Three types of inoculum in each treatment were $10 \mathrm{~g}, 20 \mathrm{~g}$, and 30 g. After that, the Mung bean seeds were covered with soil. The observation was made in two stages. The first observation was conducted in a 
greenhouse two weeks after inoculation. The second stage was observed every week for ca. two months.

\section{Data analysis}

The data were analyzed by using ANOVA. If there were significant between treatments, the Duncan Multiple Range Test (DMRT) was adopted to investigate each other's distance. The data were analyzed using the SPSS 15.0 software.

\section{RESULTS AND DISCUSSIONS}

\section{Mycorrhizal Identification}

The isolation from roots in corn obtained two mycorrhizal genera, namely, Glomus sp. and Acaulospora sp. Glomus sp. spore shape has a perfectly round shape; this genus's color was brownish yellow and transparent yellow, and reddish-yellow. The glomus walls consist of one to three layers (Figure 1), spores filled with oil.

Table 1. Plant height after treatment

\begin{tabular}{lcc|c|c}
\hline \multirow{2}{*}{\multicolumn{1}{c}{ Treatment }} & \multicolumn{4}{c}{ Plant Height (cm) } \\
\cline { 2 - 5 } & 14 DAP & 28 DAP & 42 DAP & 56 DAP \\
\hline Mix with 10 grams & 14.00 & 18.66 & $26.10 \mathrm{~b}$ & $35,20 \mathrm{ab}$ \\
Mix with 20 grams & 15.00 & 18.83 & $30.53 \mathrm{bc}$ & $35.96 \mathrm{abc}$ \\
Mix with 30 grams & 14.16 & 20.66 & $32.00 \mathrm{bc}$ & $38.86 \mathrm{~cd}$ \\
Tablets with 10 grams & 14.06 & 18.50 & $23.83 \mathrm{a}$ & $33.66 \mathrm{a}$ \\
Tablets with 20 grams & 13.33 & 19.50 & $32.16 \mathrm{bc}$ & $35.33 \mathrm{abc}$ \\
Tablets with 30 grams & 14.00 & 20.30 & $33.16 \mathrm{~cd}$ & $38.60 \mathrm{bcd}$ \\
Granular with 10 grams & 12.50 & 17.06 & $30.16 \mathrm{bc}$ & $32.83 \mathrm{a}$ \\
Granular with 20 grams & 12.00 & 17.16 & $31.70 \mathrm{bc}$ & $36.33 \mathrm{abc}$ \\
Granular with 30 grams & 13.00 & 17.83 & $36,16 \mathrm{~d}$ & $41.33 \mathrm{~d}$ \\
\hline
\end{tabular}

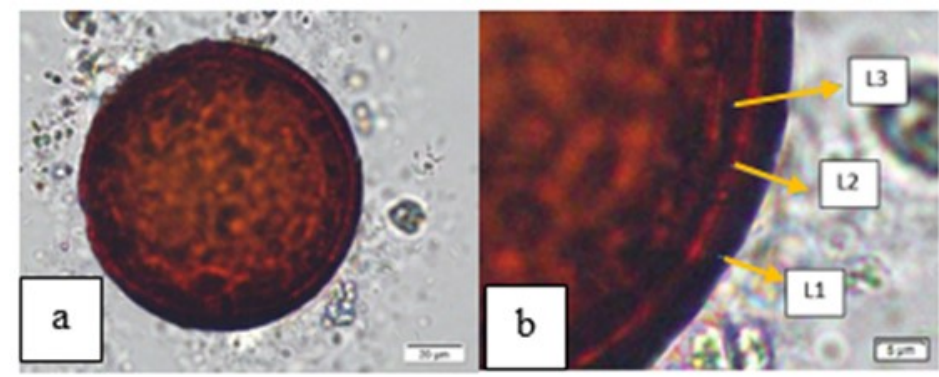

Figure 1. Glomus sp. a. Spore and b. Spore layer
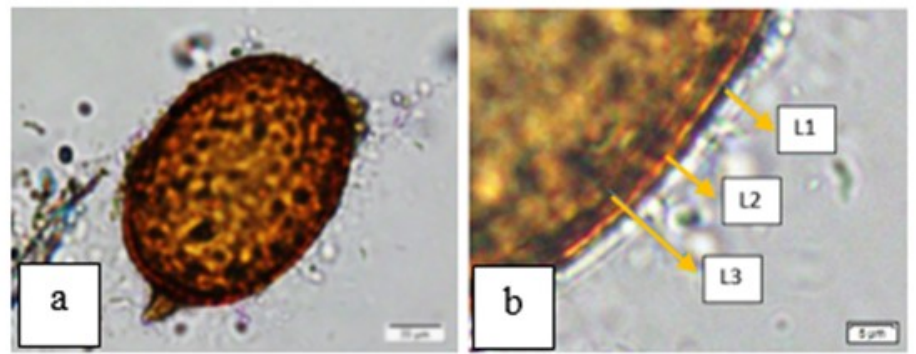

Figure 2. Acaulospora sp., a. Spores and b. Spore layer 
Table 2. Canopy and root weight

\begin{tabular}{llc}
\hline Treatment & $\begin{array}{c}\text { Plant crown } \\
\text { weight (g) }\end{array}$ & $\begin{array}{c}\text { Plant root } \\
\text { weight (g) }\end{array}$ \\
\hline Mix with 10 grams & $21,30 \mathrm{ab}$ & $10.06 \mathrm{a}$ \\
Mix with 20 grams & $22.82 \mathrm{abc}$ & $13.49 \mathrm{a}$ \\
Mix with 30 grams & $25.87 \mathrm{bcd}$ & $13.52 \mathrm{a}$ \\
Tablets with 10 grams & $18.67 \mathrm{a}$ & $8.62 \mathrm{a}$ \\
Tablets with 20 grams & $21.93 \mathrm{ab}$ & $9.29 \mathrm{a}$ \\
Tablets with 30 grams & $25.61 \mathrm{abcd}$ & $22.98 \mathrm{~b}$ \\
Granular with 10 grams & $25.63 \mathrm{abcd}$ & $9.85 \mathrm{a}$ \\
Granular with 20 grams & $29.40 \mathrm{~cd}$ & $10.54 \mathrm{a}$ \\
Granular with 30 grams & $30.69 \mathrm{~d}$ & $14.18 \mathrm{a}$ \\
\hline
\end{tabular}

Effects of Inoculum Type and Mycorrhizal on Plant Height

The results showed that the Mung bean plants applied with high doses of mycorrhizae had higher growth. The different types of inoculums and doses showed no significant difference between 14 and 28 days after. However, the observation at 42 and 56 DAP in different types of inoculum and dosage were differences in plant height (Table 1). It appears that the granules (30 grams) have a maximum plant height at 42 and 56 DAS, which was caused by the addition of a higher dose. The more mycorrhizae infect plant roots, and the stronger the growth of mung beans. According to
Putri et al. (2019), arbuscular mycorrhizae (MVA) can increase plant growth because it can increase water and nutrients' absorption by plants. Arbuscular mycorrhiza that infects the host plant's root system will produce hyphae intensively so that the plants with mycorrhizae will be able to increase their capacity in absorbing water and nutrients. Moreover, mycorrhizae are also able to stimulate plant growth hormones such as cytokinins and auxins. These cytokinin and auxin hormones play a role in cell division and elongation, one of which is in stem cells to increase plant height and number of leaves in plants.

Table 3. The number of pods, pod wet weight, and pod dry weight

\begin{tabular}{lccc}
\hline \multicolumn{1}{c}{ Treatment } & $\begin{array}{c}\text { Number of pods/ } \\
\text { plants }\end{array}$ & Wet Weight (g) & Dry Weight (g) \\
\hline Mix with 10 grams & $6.33 \mathrm{a}$ & $3.67 \mathrm{a}$ & $3.17 \mathrm{a}$ \\
Mix with 20 grams & $6.33 \mathrm{a}$ & $4.44 \mathrm{a}$ & $3.83 \mathrm{a}$ \\
Mix with 30 grams & $12.00 \mathrm{~cd}$ & $7,31 \mathrm{~b}$ & $6.62 \mathrm{~b}$ \\
Tablets with 10 grams & $6.00 \mathrm{a}$ & $3.75 \mathrm{a}$ & $3.26 \mathrm{a}$ \\
Tablets with 20 grams & $5,66 \mathrm{a}$ & $4.17 \mathrm{a}$ & $3,56 \mathrm{a}$ \\
Tablets with 30 grams & $7,33 \mathrm{ab}$ & $5,25 \mathrm{a}$ & $4.52 \mathrm{a}$ \\
Granular with 10 grams & $7,66 \mathrm{ab}$ & $4.58 \mathrm{a}$ & $4.17 \mathrm{a}$ \\
Granular with 20 grams & $9.66 \mathrm{bc}$ & $6.77 \mathrm{~b}$ & $5,88 \mathrm{~b}$ \\
Granular with 30 grams & $13.66 \mathrm{~d}$ & $9.84 \mathrm{c}$ & $8.86 \mathrm{c}$ \\
\hline
\end{tabular}


Effect of inoculum type and mycorrhizal dose on the number of pods, wet and dry pod weight

The results show that the granular $(30 \mathrm{~g})$ application provides the highest number of pods, wet and dry pod weight were 13.66, 9.84, and 8.86 $\mathrm{g}$, respectively (Table 3 ). The granular $(30 \mathrm{~g})$ has the most spores, so that the possibility of mycorrhizal infecting roots is also increasing. Mycorrhizae help plants absorb water and nutrients from the soil. The higher the uptake of water and nutrients in plants causes better metabolic processes and photosynthesis to increase plant growth ultimately. According to Prasasti et al. (2013), mycorrhizal colonization of plant roots can expand the field of root absorption in the presence of external hyphae that grow and develop through root hairs. Hyphae that penetrate the host plant will help bring nutrients closer to the host plant's rhizosphere zone so that plant growth and development become faster so that more treatments of mycorrhizal doses are given, so plant growth and yield increase.

Effect of type of inoculum on and mycorrhizal dose on the wet and dry weight of 50 seeds

The results showed that the highest wet and dry weight was granular $(30 \mathrm{~g})$, namely 3.82 and 3.20 (Table 4). It is suspected that plants with a 30 g granular treatment absorbed more nutrients than others so that photosynthesis runs well, resulting in higher crop yields. According to Prasasti et al. (2013), mycorrhiza that infects plant roots will produce external hyphae tissue that grows expansively, increasing the root capacity in water absorption and nutrients, especially phosphate $(P)$. High water and nutrients absorbed by plants make plant growth better. The phosphate element accelerates flowering and increases the percentage of fruit's interest (Marhaeni et al., 2018).

Percentage of infection and number of mycorrhizal spores per 100 gr of soil

The results indicated that the $30 \mathrm{~g}$ of the mixture showed the highest percentage of infections (73.33\%) and not significantly different with $30 \mathrm{~g}$ of Granular (Table 5). Putri et al. (2019) delineate Mycorrhizal infection in roots is influenced by the content of phosphate $(P)$ and $\mathrm{pH}$, the higher $P$ in the soil, and the more acidic the percentage of infection is not too high. High $P$ levels are not optimal conditions for mycorrhizal growth and development. In reality, the intensity of infection is not always proportional to its influence on crop yield. Infection and mycorrhizal effects are reduced with increasing phosphate available in the

Table 4. Weight of 50 seeds.

\begin{tabular}{lcc}
\hline \multicolumn{1}{c}{ Treatment } & $\begin{array}{c}\text { The wet weight } \\
\text { of } \mathbf{5 0} \text { seeds } \mathbf{( g )}\end{array}$ & $\begin{array}{c}\text { The dry weight } \\
\text { of } \mathbf{5 0} \text { seeds } \mathbf{( g )}\end{array}$ \\
\hline Mix with 10 grams & $3.24 \mathrm{abc}$ & $2.84 \mathrm{ab}$ \\
Mix with 20 grams & $3.54 \mathrm{cde}$ & $3.02 \mathrm{bc}$ \\
Mix with 30 grams & $3.64 \mathrm{de}$ & $3.02 \mathrm{bc}$ \\
Tablets with 10 grams & $3.00 \mathrm{a}$ & $2.63 \mathrm{a}$ \\
Tablets with 20 grams & $3.30 \mathrm{bcd}$ & $2.96 \mathrm{bc}$ \\
Tablets with 30 grams & $3.44 \mathrm{bcd}$ & $2.92 \mathrm{~b}$ \\
Granular with 10 grams & $3,16 \mathrm{ab}$ & $2.77 \mathrm{ab}$ \\
Granular with 20 grams & $3.65 \mathrm{de}$ & $2.96 \mathrm{bc}$ \\
Granular with 30 grams & $3.82 \mathrm{e}$ & $3.20 \mathrm{c}$ \\
\hline
\end{tabular}


Table 5. Percentage of infection and number of spores per $100 \mathrm{gr}$ of soil

\begin{tabular}{lcc}
\hline \multicolumn{1}{c}{ Treatment } & Mycorrhizal Infection (\%) & $\begin{array}{c}\text { Number of spores / 100 } \\
\text { grams of soil }\end{array}$ \\
\hline Mix with 10 grams & $13.33 \mathrm{a}$ & $9.66 \mathrm{a}$ \\
Mix with 20 grams & $43.33 \mathrm{~cd}$ & $22.00 \mathrm{e}$ \\
Mix with 30 grams & $73.33 \mathrm{f}$ & $28.00 \mathrm{f}$ \\
Tablets with 10 grams & $13.33 \mathrm{a}$ & $12.66 \mathrm{ab}$ \\
Tablets with 20 grams & $30.00 \mathrm{bc}$ & $17.66 \mathrm{c}$ \\
Tablets with 30 grams & $56.66 \mathrm{de}$ & $22.33 \mathrm{e}$ \\
Granular with 10 grams & $16.66 \mathrm{ab}$ & $14.00 \mathrm{~b}$ \\
Granular with 20 grams & $46.66 \mathrm{~d}$ & $21.66 \mathrm{~d}$ \\
Granular with 30 grams & $63.33 \mathrm{ef}$ & $29.33 \mathrm{f}$ \\
\hline
\end{tabular}

on crop yield. Infection and mycorrhizal effects are reduced with increasing phosphate available in the soil. If the phosphate is available for excessive plants, then plants' growth without mycorrhizae will be better than plants with mycorrhizal.

The highest number of spores / 100 grams of soil as shown in the granular treatment with a dose of 30 grams (29.33 spores) and not significantly different from mixed treatment $(30 \mathrm{~g})$ (Table 5). While the lowest in mixed treatment with a dose of 10 grams (9.66 spores). It is assumed that the germination time is different for each spore. (Smith and Read, 1996) state that each genus has a different time at the time of germination and has a dormant period. The genus Acaulospora takes three months to germinate, whereas Glomus is faster, 2 to 4 days. The spore species carried by each treatment were the same. Mycorrhizal species used are Glomus sp. and Acaulospora sp. It is suspected that the Glomus distribution is broader than that of the Acaulospora genus, which is in line with Suryati (2017); the high number of genus Glomus species results in a wider distribution than other genera.

\section{CONCLUSION}

The greater the dose of mycorrhizal application, the treatment mixture, tablets, and granular can provide better results than low doses. In general, $30 \mathrm{gr}$ granular treatments showed the highest growth and yield of plants.

\section{REFERENCES}

Campos, P., F. Borie, P. Cornejo, J.A. LópezRáez, Á. López-García, et al. 2018. Phosphorus Acquisition Efficiency Related to Root Traits: Is Mycorrhizal Symbiosis a Key Factor to Wheat and Barley Cropping. Front. Plant Sci. 9: 752. https://www.frontiersin.org/ article/10.3389/fpls.2018.00752.

Chen, M., M. Arato, L. Borghi, E. Nouri, and D. Reinhardt. 2018. Beneficial Services of Arbuscular Mycorrhizal Fungi - From Ecology to Application. Front. Plant Sci. 9: 1270. doi: 10.3389/fpls.2018.01270.

Hastuti, D.P., S. Supriyono, and S. Hartati. 2018. Pertumbuhan dan Hasil Kacang Hijau (Vigna radiata, L.) pada Beberapa Dosis Pupuk Organik dan Kerapatan Tanam. Caraka Tani J. Sustain. Agric. 33(2): 89. doi: 10.20961/ carakatani.v33i2.20412. 
Jansa, J., R. Finlay, H. Wallander, F. Smith, and S. Smith. 2011. Role of Mycorrhizal Symbioses in Phosphorus Cycling. Phosphorus in Action,. p. 137-168

Kurniawati, E., N. Diana, and Delvian. 2019. Provision of micoriza arbuscula in some types of grass to the degree of infection and phosporus uptake. IOP Conf. Ser. Earth Environ. Sci. 260(1): 25-29. doi: 10.1088/1755-1315/260/1/012182.

Marhaeni, A.T., E.S. Muliawati, and R.B. Arniputri. 2018. Rasio N-NO3-:P dan Pengaturan Kepekatan Larutan Nutrisi Untuk Pembungaan Waluh Berbasis Hidroponik Substrat. Agrotechnology Res. J. 2(2): 69. doi: 10.20961/agrotechresj.v2i2.22888.

Musfal. 2017. Potensi Cendawan Mikoriza Arbuskula Untuk Meningkatkan Hasil Tanaman Jagung. J. Litbang Pertan. 29(4): 154-158. doi: 10.21082/jp3.v29n4.2010.p154 -158 .

Prasasti, O.., K.I. Purwani, and S. Nurhatika. 2013. Pengaruh Mikoriza Glomus fasciculatum Terhadap Pertumbuhan Vegetatif Tanaman Kacang Tanah yang Terinfeksi Patogen Sclerotium rolfsi. J. Sains Dan Seni Pomits 2 (2): 1-16.

Putri, T.E., Yuliani, and G. Trimulyono. 2019. Penggunaan Mikoriza Vesikular Arbuskular ( MVA ) Genus Glomus untuk Meningkatkan Pertumbuhan dan Produksi Tanaman Kacang Hijau ( Vigna radiata ) Pada Cekaman Air The Use of Versicular Arbuscular Mycorrhizal
( VAM ) Glomus Genus to Increase The Growth and. LenteraBio 8(2): 107-112.

Ramadhani, C., E. Fuskhah, and E. Dwi Purbajanti. 2020. Growth and yield of Mung bean (Vigna radiata L.) as affected by Rhizobium sp. bacteria inoculant and frequence of watering. IOP Conf. Ser. Earth Environ. Sci. 518(1). doi: 10.1088/17551315/518/1/012003.

Samanhudi, S., B. Pujiasmanto, A. Yunus, Supyani, S. Suntoro, et al. 2017. The effect of manure and mycorrhiza application to the soil microbes biodiversity in terms of increasing soybean yield in marginal land in Indonesia. Bulg. J. Agric. Sci. 23: 994-1003.

Smith, S.E., and D. Read. 1996. Capture. 2nd ed. Academic Press, San Diego.

Suryati, T. 2017. Studi Fungi Mikoriza Arbuskula di Lahan Pasca Tambang Timah Kabupaten Bangka Tengah Study of Arbuscular Mycorrhizal Fungi in Tin Post-Mining Land of Central Bangka Regency. J. Teknol. Lingkung. 18(1): 45-53.

Tommerup, I.C. 1992. 2 Methods for the Study of the Population Biology of Vesiculararbuscular Mycorrhizal Fungi. In: Norris, J.R., Read, D.J., and Varma, A.K.B.T.-M. in M., editors. Academic Press. p. 23-51

Widiyawati, I., T. Harjoso, and T.T. Taufik. 2016. Aplikasi pupuk organik terhadap hasil kacang hijau (Vigna radiate L.) di ultisol. Kultivasi 15 (3): 159-163. doi: 10.24198/ kultivasi.v15i3.11902. 